\title{
Opinions on the Impacts of the TEOG System from Teachers Whose Courses are not Included in the TEOG Exam
}

\author{
Seher ULUTAŞ** $\quad$ R. Nükhet ÇIKRIKÇI ***
}

\begin{abstract}
The object of this study is to determine of teachers' opinions on the impacts of exam for the Transition from Basic Education to Secondary Education TEOG system on their teaching activities in visual arts, technology and design, music and physical education courses that are not covered by the TEOG exam. This research was conducted as a survey study and the study group was determined by the purpose of sampling strategy, data analysis plan and easy accessibility approach. This research was carried out with 35 teachers who teach visual arts, physical education, technology and design, and music courses in public schools in Ankara. Teachers' opinions were obtained with a form containing five open-ended questions and demographic and occupational characteristics of the teachers. A descriptive analysis approach was applied to the written opinions of the teachers. As a result of this research according to the opinions of teachers; visual arts, technology and design, music and physical education courses which are not included by the TEOG exams were considered to be insignificant by students, school administrators and parents. In addition, teachers stated that the TEOG system affected their teaching and evaluation activities negatively in the classroom, and the teachers were unable to evaluate their students objectively due to the TEOG system, and students, administrators and parents expected or demanded the teacher to give higher grades. Because of these situations, the relations between the teachers, students, school administrators and parents were affected negatively.
\end{abstract}

Key Words: TEOG system, common exam, teachers’ opinions.

\section{INTRODUCTION}

One of the most important wealth of a country is manpower; i.e., human capital. It is accepted all over the world that the quality of manpower affects the development and prosperity of countries, and what determines the quality of manpower is the quality of education. For this reason, both politicians and parents desire that children and young people receive education in quality schools as part of the process of developing skilled future generations. The level of the education in a school is affected by various factors, such as the location of the school, the characteristics of the students, the support of the families, the socio-economic characteristics of the families, and the quality of the teachers. Since these factors are not at the same level in each school, the standard of education and level of students' achievement are not the same in every school. National and international evaluation studies in Turkey have shown that there are significant achievement differences between school types in Turkey (MEB, 2010; MEB, 2015; MEB, 2016b; ERG, 2017). In addition, there are significant differences between high schools in terms of university admission rates in Turkey (MEB, 2012). For this reason, parents want their children to be educated in secondary schools that have a record of higher student success. However, selecting which children attend a public school is based on the result of the central common exams in Turkey.

In Turkey from 1997 onwards, the transition from primary education to secondary education was carried out by the Ministry of National Education (MoNE) every year under the name of Exam for

\footnotetext{
* An early draft of this paper was presented in "IV International Eurasion Educational Research Congress 2017", Pamukkale University Denizli

** Dr., Ministry of National Education, Ankara, Turkey, e-mail: seherulutas@yahoo.com.tr, ORCID ID: orcid.org/00000002-4124-2140

*** Prof. Dr. Istanbul Aydin University, Faculty of Arts and Humanities, Istanbul, Turkey, e-mail: nukhet0405@ gmail.com, ORCID ID: orcid.org/0000-0001-8853-4733
}

To cite this article:

Ulutaş, S., \& Çıkrıkçı, N., R. (2019). opinions on the impacts of the TEOG system from teachers whose courses are not included in the TEOG exam. Journal of Measurement and Evaluation in Education and Psychology, 10(1), 68-79. DOI: 10.21031/epod.342086 
Secondary Education (ESE/OKS) for eighth-grade students. In 2008, OKS was abolished and SBS (Exam for Proficiency Level-EPL) was implemented centrally by MoNE at the end of the sixth, seventh and eighth grades, limited to the acquisition/objectives in the curricula of that year (MEB, 2012, pp. 1-2).

SBS has been gradually eliminated since 2010 and the system of Transition from Basic Education to Secondary Education (TEOG) began to be implemented in the 2013-2014 academic year. In this system, placement in secondary education is based on the achievement scores of the student at the end of the year and the scores obtained from central common exams in the eighth grade of schools. In this system, the central common exams which comprise Turkish, mathematics, science, religious culture and ethics, the history of the Turkish Republic, revolution and Ataturkism, and foreign language courses are given once in each semester. The TEOG central exam has certain common features, such as the opportunity for make-up exams, being implemented in two school days, covering the subjects studied until the exam day, duration of the exams being similar to that of an ordinary exam, false answers not affecting the scores of correct answers, and each student taking the exams in their own schools. According to MoNE, the aim of the TEOG system is to strengthen the student, teacher and school relationship, make teachers and school's role more effective in the educational process, ensure simultaneous implementation of national curricula across the country, and reduce students' test anxiety. Other objectives include increasing teacher's professional performance, reducing the need for out-of-school education institutions, monitoring and evaluating implementation of curriculum and student achievements objectively, and remove the negative effects of a single session test MEB, 2013; MEB, 2014).

In the TEOG system, the calculation of the points for placement in secondary education institutions is as follows: The weighted common exam scores (AOSP) obtained from the common exams held every semester are calculated by multiplying the score of each course by four coefficients for Turkish, mathematics, and science courses, and two coefficients for the history of the Turkish Republic, revolution and Ataturkism, foreign language, and religious culture and ethics courses. The total possible score is 700 points. In the calculation of the points for secondary school placement, student's achievement scores at the end of the sixth, seventh and eighth grades and AOSP of the eighth grade are collected, and the total score obtained is divided into two to obtain the "basis score for placement in secondary education institutions". This score is based on a possible total of 500 points (MEB, 2013, MEB, 2014, MEB, 2016a).

In Turkey, there are several studies about this exam system. According to the results of one of these studies, teachers have positive and negative opinions about the TEOG system. The positive aspects of the system are that students take their exams in their own schools, the exam is applied in two semesters, a compensatory exam is offered, and correction formula is not used in scoring. In addition, in this research, teachers stated that the standard of the school will increase because of the importance of the assessment of the courses in the TEOG system. Teachers also stated that this exam positively affected the student's interest and motivation toward courses and reduced student absenteeism. The negative aspects of the system are that it does not reduce the necessity tutoring and attending private cram courses and that the reliability of exams are inadequate (Şad \& SSahiner, 2016). Another study that surveyed the opinions of teachers and students found that the TEOG system was objectionable in terms of equality of opportunity in education, but not using correction formula against the chance factor in the calculation of test scores and the test being conducted in students' own schools increased their motivation. It was also found that the year-end achievement score had positive impact on school success because of participation in the evaluation in the TEOG system. It was also determined that the TEOG system affecting the achievement scores of the year-end in secondary education entrance was the reason for the increase in interest in lessons except for the six basic courses (Özkan \& Özdemir, 2014). In another study about the TEOG system, the positive aspects expressed by the students were application of the central common exams in a modular way, having a break between the exams, the test consisting of multiple choice questions, and wrong answers not negating correct answers. However, the students generally regarded central exams as stressful (Öztürk \& Aksoy, 2014). In research undertaken with science teachers (Atila \& Özeken, 2015), the participants stated that the 
common test of the TEOG system affected the functioning of the teaching, and they tended to focus on solutions for test questions. A significant number of the teachers stated that this situation caused the problem of objectivity, and thus they hesitated about grading their students. Some of the teacher participants stated that the school administrators wanted the students to be seen as successful in their institutions, and since the parents knew that the grades given by the teachers affected the secondary school placement, they wanted to meet with the teachers to discuss the grades, which put pressure on the teachers. Demirtaşl1 (2016) gathered the opinions of primary school teachers about the effects of the TEOG system on teaching and evaluation activities). The teachers explained that the preparation process for the TEOG system common exams had a negative effect on the teaching and evaluation activities in the classroom because the students wanted to engage in test practice in most of the class time. Furthermore, the students' anxiety about the test and spending time on preparing for it meant that they did not participate in social, cultural and sports activities in the school.

It is seen that central exams, such as the TEOG system have positive and negative effects on students and educational activities in most countries. In a study conducted in the United States, more than $80 \%$ of the students stated that they needed to increase their studying time due to this type of exams, and this reduced the time spent on extracurricular activities. It was found that nearly half of the students stated that there was a decrease in extracurricular activities. In addition, over $80 \%$ of the students stated that they felt depressed, anxious and embarrassed after the exams (Cornell, Krosnick \& Chang, 2006). In a study concerning all primary and secondary school teachers in the city center of Virginia on the effects of a central exam on learning and teaching, more than $80 \%$ of teachers believed that teaching had changed due to the implementation of these exams. Teachers expressed that they ignored lessons that were not within the scope of the test and focused more on lessons within the scope of testing. More than one-third of these teachers stated that they were concerned that the excessive focus on the lessons in the exam limited or eliminated the teaching time for lessons or activities that were not assessed. The responses of more than $50 \%$ of teachers who participated in the survey showed that the main purpose of the teaching was to improve students' performance in these tests and complained about "teaching to the test" (Sullivan, 2006). According to interviews with participating teachers in a survey of the National Assessment Program (NAPLAN), a centralized test in Australia, it was stated that the effects of the test on the students and curriculum were not entirely negative. The test supported the increasing focus on students' high-level education, reaching full aims in the curriculum, and critical reading-writing and arithmetic skills to become participant citizens after completing secondary school. In addition, the results of the test help teachers improved their professional development and teaching practices. However, concerns were reported by teachers that the test had some negative effects on curricula and students. The teachers stated that the test intensified the curriculum due to the need to study for the test and engage in test-solving exercises, reducing the time allocated for the lessons other than mathematics and literacy. Furthermore, teachers commented that because of the test, some of the students felt stressed or sick, were tearful before the exam or afraid of their parents' reactions, and had insomnia (Dulfer, Polesel, \& Rice, 2012). According to a study conducted by the New York State Education Department (2004), the positive effects of high-stakes exams on students and teachers were that they provided students with clear information about their skills and encouraged them to study harder. However, this type of test had negative effects, such as students being disappointed with their results, discouraging them from studying, making them more competitive, and lowering their opinion of the value of grades and evaluation.

Thus, central common examinations have positive and negative effects on students and education. In Turkey, research was carried out concerning the impact of the TEOG system and common exams on education and teaching; however, there is no research on how the test affects the teachers ' classroom practices and their relations with the stakeholders regarding education.

The aim of this study is to determine the effects of the TEOG system on teachers 'practices in classroom and teachers' relationships with students and other stakeholders in visual arts, technology and design, music and physical education lessons that are not covered by the TEOG exams. This study is important in terms of providing an understanding of the impacts of the TEOG central exam system which is applied in the transition to high schools in Turkey. Such high-stake exams generate exam 
based teaching and learning activities at schools and manipulate teachers' relationships with their students in whole lessons. The study is also considered important in terms of identifying problems in these dimensions and the planning of educational policies that might resolve them.

\section{Purpose of the Study}

The general aim of the research is to gather the opinions of teachers who teach visual arts, technology and design, music and physical education lessons that are not covered by the common exams in the TEOG system, and to determine how this affects their relations with the students and other stakeholders, and education and training practice and evaluation activities in the schools. For this purpose, answers to the following questions were sought:

1. How does the TEOG system affect the communication between teachers and students?

2. How does the TEOG system affect classroom teaching activities?

3. How does the TEOG system affect the activities of evaluating student achievement?

4. How does the TEOG system affect the teachers' relationships with school administrators and their assistants?

5. How does the TEOG system affect the teachers' relationships with parents?

\section{METHOD}

This research was conducted as a survey study, in which the purpose is to collect data to determine a specific feature of a group and create a picture of the existing situation in the field of research (Büyüköztürk et al. 2013).

\section{Study Group}

In the research, a typical case sampling method was chosen from the purposeful sampling strategy. This method requires the collection of information from the sample by determining a situation that is typical of a number of situations in the universe (Büyüköztürk et al. 2013). Fowler (2009) recommends that the sample size should be determined in accordance with the analysis plan of the studying data (as cited in Creswell, 2014, pp. 159). In this study, the group size was determined in accordance with the data analysis plan and easy accessibility. This research was carried out with 35 teachers who teach visual arts, physical education, technology and design, and music courses in seven public schools in Ankara. Table 1 shows the distribution of the participant teachers according to the branch, gender, service year, and grade that they teach.

Table 1. Information on the Study Group

\begin{tabular}{lll}
\hline & & Number of Teachers \\
\hline \multirow{3}{*}{ Branches } & Music & 5 \\
& Visual arts & 6 \\
& Physical education, & 9 \\
& Technology and design & 15 \\
\hline \multirow{2}{*}{ Gender } & Woman & 23 \\
& Man & 12 \\
\hline \multirow{3}{*}{ Service year } & Between 1-5 years & 4 \\
& Between 6-10 years & 3 \\
& Between 11- 15 years & 7 \\
& Between 16-20 years & 11 \\
\multirow{2}{*}{ Grade that they teach } & More than 20 years & 10 \\
\hline & 5-8 & 21 \\
& $7-8$ & 14 \\
\hline
\end{tabular}




\section{Instrument and Data Collection}

In this study, a semi-structured survey form with five open-ended questions was used. This instrument was to allow teachers to express their opinions freely on how the TEOG system affects their teaching and evaluation processes and relations with stakeholders in their courses. Teachers were asked to respond in writing to the questions in the survey form created by the researchers. With the survey form, no personally identifiable information other than their demographic and professional characteristics was received. Researchers' contact information was also given to them to learn the results of the study. The following open-ended questions were asked to the teachers who were included in the purpose of the study:

1. How does TEOG affect your general communication with students?

2. How does TEOG affect your classroom teaching activities?

3. How does TEOG affect your assessment activities?

4. How does TEOG affect your relationships with administrators and their assistants?

5. How does TEOG affect your relationships with the parents?

\section{Data Analysis}

A descriptive analysis approach was applied to the written opinions of the teachers. In this approach, the data are summarized and interpreted according to the previously determined themes. The purpose of this analysis is to present the findings to the readers in an organized and interpreted way. In descriptive analysis, direct quotations are often given in order to reflect the views of individuals in a striking way (Yıldırım \& Şimşek, 2005). In the study, firstly, according to the research questions, each of the 35 forms containing the teachers' responses was examined one by one. Essential opinions/themes and keywords in the opinions were extracted from the forms. Secondly, the selected words for each question and corresponding to the sub-themes were identified. This study was examined under five themes and 22 sub-themes. Expressions describing the sub-themes specified in all response papers were counted. As a result, the frequencies of each question and sub-themes were calculated according to the themes. In order to ensure reliability in coding, the consistency between the coding for each question and the subcategory was examined by two experts in addition to two measurement experts. The level of reliability was calculated based on the total consistency and inconsistency ratio of two experts regarding the codes (Tavşanc1l \& Aslan, 2001). It was determined that the reliability levels of the evaluators calculated for each question and sub-theme ranged between .100 and .33 in this study. Sub-theme expressions with low reliability were reviewed and changed, and returned to evaluators, after which the final level of reliability was found to be .80 for the whole themes and sub-themes. The placement consistency of opinions in the sub-themes should be between $70 \%$ and $100 \%$ for each question and sub-theme. There should be at least $70 \%$ consistency between the coders (Hall \& Houten 1983). In this regard, it was understood that an acceptable level of consistency was achieved; thus, the frequencies of responses in each question and sub-theme were calculated according to the themes.

\section{RESULTS}

In this section, the findings obtained in relation to the objectives of the research are summarized and interpreted.

\section{The Impact of the TEOG System on Teacher and Student Relations}

Table 2 shows the frequency distributions of teachers' responses to the first research question: "How does the TEOG system affect the communication between teachers and students?" 
Table 2. Distribution of Teachers' Views According to Sub-Themes

\begin{tabular}{ll}
\hline Sub-Themes & Frequency \\
\hline Establishing a note-based communication with students & 4 \\
Conflict with students in the course process & 2 \\
Conflicts due to students' stress / fear / anxiety & 6 \\
Negative impact on relationships in general & 8 \\
No effect & 7 \\
\hline
\end{tabular}

Table 2 shows that one-third of the respondent teachers $(f=8)$ reported that the TEOG system generally had a negative impact on their communication with their students, while the other third of the respondent teachers indicated that they were in conflict with students due to the process of the course, lack of discipline, and test anxiety. However, some of the teachers $(f=7)$ stated that the test had no effect on their communication with the students. Some teachers $(f=4)$ also pointed out that their communication with students was focused on the grade and students only participated in this course to obtain high grades. Examples of the teachers' views on the effects of the TEOG system on teachers' communication with students are given below:

K2B "Since our lesson does not include the TEOG group, the students evaluate it as not important."

K6S "It affects our communication with the students negatively. Apart from TEOG, everything seems to be futile, and I'm having trouble controlling the class."

K3T "Communication with students always takes place on the bases of grades."

K12S "Students perceive the TEOG test as a vital event. Students are not interested in our courses. "

\section{The Impact of the TEOG System on In-Class Teaching Activities}

Table 3 shows the frequency distributions of teachers' responses to the second question of the research, "How does the TEOG system affect the activities in the classroom?".

Table 3. Distribution of Teachers' Views According to Sub-Themes

\begin{tabular}{ll}
\hline Sub-Themes & Frequency \\
\hline Students do not care about the lesson & 20 \\
Students do not show interest in the lesson & 21 \\
Students do not undertake the duties and responsibilities related to the lesson & 12 \\
Students want to take practice tests for TEOG during class hours & 12 \\
\hline
\end{tabular}

Table 3 shows that the majority of the teachers $(f=20)$ stated that the students did not care about the course and this affected the education and training activities negatively. Most of the teachers ( $\mathrm{f}=21)$ stated that because of the common exams, the students did not show interest in the activities of these courses and they did not participate in these activities. In addition, some of these teachers $(f=12)$ expressed that students did not want to undertake their duties and responsibilities related to the courses, and they only wanted to study for the exam in the courses. The teachers also commented that the students always wanted to take practice tests. Some of the teachers' views on the effectiveness of the TEOG system in in-class teaching activities are as follows:

K6S "I cannot carry out effective teaching in the classroom. It takes a short time to draw the attention of students. Students always tend to study for TEOG and answer the questions in practice tests."

K9B "Because they want to be successful in the exam, the children want permission to study for the TEOG exam in this lesson." 
K10T "Students do not care about to other courses apart from of TEOG exam. For this reason, in terms of the students the purpose of the courses cannot be realized exactly.

K21T "Children especially want to solve the test in our courses."

\section{The Impact of the TEOG System on the Evaluation Activities}

Table 4 shows the frequency distribution of teachers' answers on the third question of the research, "How does the TEOG system affect the activities of evaluating students' success?".

Table 4. Distribution of Teachers' Views According to Sub-Themes

\begin{tabular}{ll}
\hline Sub-Themes & Frequency \\
\hline Students want to get high grades. & 6 \\
Administrators interfere with teachers' grades. & 10 \\
Parents expect and request high grades from teachers & 6 \\
Teachers do not make fair evaluations / They give inflated grades & 12 \\
No effect & 5 \\
\hline
\end{tabular}

Table 4 shows that the majority of participant teachers stated that students, parents, and administrators $(\mathrm{f}=22)$ expected or demanded high grades from the teachers in these courses. A significant number of teachers $(f=13)$ also stated that they had to give an inflated grade to their students and sometimes they did not make a fair evaluation because of the TEOG system. Conversely, some teachers $(f=5)$ stated that the TEOG system had no effect on the evaluation activities. Some of the teacher's views about the effects of the TEOG system on assessment activities are as follows:

K1S "Students want to get high grades. They can ask for it as natural rights. "

K2B "There is a pressure on us .... We cannot give low grades. We give high grades to not lower the grade average."

K8T "School administrators say that for all of the courses, which are not covered by TEOG exam, grades should be high. That's why they interfere with the teachers' grades and say that all grades should be higher."

K9B "We have to raise the grades so that students who are good at other courses do not fail."

\section{The Impact of the TEOG System on Teacher's Relationship with School Administrators}

Table 5 shows the frequency distributions of teachers' responses to the fourth question of the research, "How does the TEOG system affect the relationship of teachers with school administrators and assistant managers?".

Table 5. Distribution of Teachers' Views According to Sub-Themes

\begin{tabular}{ll}
\hline Sub-Themes & Frequency \\
\hline There is conflict due to the pressure to give high grades & 9 \\
These courses are not considered / unnecessary & 13 \\
No negative effect & 12 \\
\hline
\end{tabular}

Table 5 shows that a significant number of participant teachers $(f=12)$ stated that the TEOG system did not adversely affect their relations with school administrators and manager assistants, others teachers $(f=13)$ stated that school administrators and their assistants cared about the courses which were within the scope of the common exam, that they did not care about the courses outside the scope 
of the common exam. In addition, they asked their teachers to implement practice TEOG tests in these courses. Some of the teachers $(f=9)$ also mentioned that administrators asked them to give high grades to their students, which also caused tension and conflict between them. Some of the teachers' views on the effects of the TEOG system on school administrators and manager assistants and teacher relations are as follows:

K6S "The test (TEOG) negatively affects our relationships. When parents complain about the grades, the administrators tell us to raise the grades. Because there is no one regards to our course at our school, there is permanent stress in such events."

K10T "Generally, like students, administrators do not give importance to the courses outside of the scope of TEOG. They do not provide any opportunity to achieve the purpose of the lesson; on the contrary, they generally put obstacles in the way."

K11B "The relationships are bad because our course is seen as unessential and worthless. For students, only mathematics, English etc. are important."

\section{The Impact of the TEOG System on Teachers' Relationship with Parents}

Table 6 shows the frequency distributions of the teachers' responses to the fifth question of the survey, "How does the TEOG system affect teachers' involvement with parents?".

Table 6. Distribution of Teachers' Views According to Sub-Themes

\begin{tabular}{ll}
\hline Sub-Themes & Frequency \\
\hline Parents do not care about the courses & 13 \\
Conflict due to parents' request for high grades & 6 \\
Parents want students not to participate in activities or be assigned homework & 7 \\
Exam-oriented training expectations & 4 \\
No effect & 7 \\
\hline
\end{tabular}

Table 6 shows that a significant number of the participant teachers $(\mathrm{f}=13)$ stated that the parents did not give importance to these courses. Some of the teachers $(f=7)$ also mentioned that the parents did not ask their children to participate in activities in these courses and asked the teachers not to give assignments related to these courses. However, many teachers commented that the TEOG system had no effect on the relationship with the parents. Some teachers $(f=6)$ also addressed the presence of conflict between parents and teachers due to the expectation of test-oriented education and high grades for their children. Some of the teachers' statements about the effects of the TEOG system on the relationship with the parents are as follows:

K2B "The families are very worried. They do not allow students to participate in extracurricular activities."

K6 S "Parents complain about homework, research, etc. in the visual arts course because they think that their children cannot study for the TEOG exam. That's why they say that assignments like this should not be given."

K19 $\mathrm{T}$ "The parents does not care about the courses that are not covered by the TEOG exam, and they ask the teachers -to give the student 100 points."

K8 $\mathrm{T}$ "When the time for school report arrives, we are in conflict with the parents because of our grades. We are trying to convince them that our courses are important. But they think that if a lesson is not included in the TEOG exam, it is not important or necessary." 


\section{DISCUSSION and CONCLUSION}

The findings of this research which aimed to determine the effects of TEOG system on teaching and learning processes in visual arts, technology and design, music and physical education courses and teachers' relations with students and other stakeholders were evaluated in terms of how the TEOG application was related to the objectives of MoNE. For MoNE, one of the aims of TEOG is to strengthen the relationship between student, teacher and school, and to make the role of teachers and school more effective in the education process. According to the findings of this research, the TEOG system, in contrast to the purpose of MoNE, has made the situation "more tense and negative" instead of "strengthening student, teacher and school relations". The exam creates conflict between the teachers and students due to the teaching process and the anxiety and stress experienced by the students. Thus, this finding does not coincide with the aim of MoNE, which states that "the central common examination will reduce the test anxiety by spreading it to the process". Similar results regarding the TEOG system were obtained by Öztürk and Aksoy (2014) and Demirtaşl1 (2016). The results were similar in other studies, which also showed that central examinations caused stress, anxiety and insomnia in students, and students felt sick, depressed, anxious and embarrassed upon receiving the test results (Cornell, Krosnick \& Chang, 2006; Dulfer, Polesel, \& Rice, 2012).

According to the results of the research, students did not care about these courses, pay attention, or fulfill their duties or responsibilities related to these courses, and this exam had a negative impact on educational activities. These results contradict Özkan and Özdemir (2014)'s conclusion that "TEOG will lead to an increase in students' interest in the courses outside the scope of the exams because of the effect of year-end scores on the TEOG process." These findings also contradict the result of the research of Şad and Şahiner (2016), in which the participant teachers stated that the importance of the courses and teacher evaluation would increase because of the TEOG tests which affected assessment in the classroom. In addition, the teachers thought that the student's interest and motivation related to the course would be positively affected and student absenteeism could be reduced." A similar result was reached by Sullivan (2006). In that research, the teachers perceived that high-stake testing had changed the focus of instruction toward subjects that were tested by high-stake exam. Overall, $52 \%$ of the teachers perceived that this increased focus on the test and decreased instructional time for other non-tested lessons reduced student access to non-core content, such as art, music, physical education and computer/technology.

According to the teachers' opinions in the current study, one of the results obtained related to the course process is that "students want to do practice tests for the common tests and study on the courses within the scope of the common test.". This outcome coincided with the findings of Atila and Özeken (2015) in that "a significant part of the science teachers stated that TEOG exams affected the way the course was given and engaged students in taking practice tests during the class hour". The research of Zorlu and Zorlu (2015) concurred, stating that "the students in the seventh and eighth grades asked the teacher to teach the courses for the exams.". These results from different research are supported by the conclusion reached by Buyruk (2014) that "central exams led to a more exam-centered form of education in schools."

For MoNE, one of the other aims of the TEOG system is to monitor and evaluate student achievement objectively. According to the findings obtained from the research, a significant number of the teachers were unable to measure and evaluate their students objectively due to the TEOG exams, and they were forced to give inflated grades to their students. In addition, more than half of the participants in the current study stated that students, administrators and parents expected or demanded the teacher to give higher grades. These results contradict the aim of the TEOG system, which is "objectively monitoring and evaluating student achievements". In particular, it is not possible to determine whether the evaluation is appropriate for this purpose in the courses covered by the exams. This finding similar to the research of Atila and Özeken (2015), who found that due to the TEOG tests, the teachers hesitated to give grades. Almost all science teachers give their students nearly the same performance and project grades with the scores obtained from the TEOG exams. However, this finding contradicts with the results of the study by Şad and Şahiner (2016). The authors determined that the results of the TEOG 
exam will increase the importance of the courses and teacher assessment because of the impact on the student's achievement grade in classroom.

Although one-third of the teachers who participated in the study stated that the TEOG system had no negative impact on their relations with the administrators, more than one-third of the teachers suggested that the administrators did not care about the courses that were the subject of the research or considered the courses unnecessary. Similarly, about one-third of the teachers stated that they received requests from the administrators to give higher grades to students, which negatively affected their relations with the administrators. These findings are similar to the results of Atila and Özeken (2015)'s research in that some of the science teachers said that because administrators asked the teachers to increase their students' achievement in their own institutions, this caused pressure on the teachers.

According to the findings from the research, some teachers who participated in the study reported that central examinations conducted within the scope of the TEOG had no impact on their relations with parents, but more than one-third of the participant teachers believed that parents did not care about their courses. So, the teachers stated that the test system had a negative impact on their relationship with parents. In addition, some teachers reported that the parents requested them to give higher grades for children, which led to conflict between them. This finding is in agreement with the research of Atilla and Özeken (2015), who reported on the awareness of parents concerning the importance of grades given by teachers for the placement of their children in secondary education; thus, they wanted to meet the teachers to discuss students' grades, and this caused pressure on the teachers. Moreover, in this study, some teachers stated that parents did not want their children to participate in the internal and external activities in school because of the exam. They also did not want the teachers to give any homework in these courses. As a result of research conducted by MoNE (2010), it was found that the SBS preparation process led children to be significantly distanced from sports, social and cultural activities. Similar results were obtained in a study conducted by Cornell, Krosnick and Chang (2006), who showed that about half the students reported a decrease in extracurricular activities due to the central examination.

In conclusion, students, school administrators and parents do not appear to care about the courses that are not within the scope of the TEOG exams, and this adversely affects the relations between the teachers who present these courses and the students, administrators, and parents. In addition, such high-stake exams have a negative impact on the educational practices and evaluation activities in these courses. However, as stated in the Turkish National Education (MEB, 1973), it is aimed that young people who will determine the future of our country will be educated to be "constructive, creative and productive people who have a balanced and healthy personality and character from the care of body, mind, morality, spirit and emotion; the power of free and scientific knowledge. In addition, the 10th Development Plan (Ministry of Development, 2013, s. 32) and higher-level policy documents, such as the MoNE Strategic Plan (Strategy Development Presidency, 2015) stated that in order to increase the students' mental and physical development and their skills in all educational levels, social, artistic, sportive and cultural activities should be given more attention, and the participation rate of the students should be increased. To achieve these objectives, courses, such as physical education, music and visual arts have an important role, as well as the academic content applied in educational institutions. However, it will be difficult to achieve these objectives if these courses are not properly taught in schools. For this reason, to exclude these courses from the TEOG exams will make it difficult to educate individuals in the qualifications that are planned in the educational institutions. In order to achieve the objectives of the Turkish National Education and higher-level policy documents, emphasis should be given on the courses mentioned above, as well as the academic content of courses in schools. For this reason, weight of student's grade point average based on primary academic courses and other courses should be increased in the computation of the TEOG exam score. In this way, school achievement can be relatively important to entrance secondary education.

As in all research, there are some limitations to this study. The main limitation is that the results were obtained from a small group. In subsequent studies, it would be useful to conduct a comprehensive survey of more structured materials with the views of more teachers working in schools in different 
regions and characteristics. Thus, comparing teachers' opinions according to variables, such as duration of service, class and school size, as well as eliciting students' views in a similar way will contribute to the field.

\section{REFERENCES}

Atila, M. E. \& Özeken, Ö. F. (2015). Temel eğitimden ortaöğretime geçiş sınavı: Fen bilimleri öğretmenleri ne düşünüyor? Ondokuz Mayis University Journal of Faculty of Education, 34(1), 124-140. DOI: 10.7822/omuefd.34.1.7

Buyruk, H. (2014). Öğretmen performansının göstergesi olarak merkezi sınavlar ve eğitimde performans değerlendirme. Trakya University Journal of Education, 4(2), 28-42.

Büyüköztürk, Ş., Çakmak, E. K., Akgün, Ö. E., Karadeniz, Ş. \& Demirel, F. (2013). Bilimsel araştırma yöntemleri. Ankara: Pegem Akademi.

Cornell, D. G., Krosnick, J. A., \& Chang, L. (2006). Student reactions to being wrongly informed of failing a high-stakes test: The case of the Minnesota basic standards test. Educational Policy, 20(5), 718-751.

Creswell, J. W. (2014). Nitel, nicel araştırma deseni ve karma yöntem yaklaşımları (S. B. Demir, Translation). Ankara: Eğiten Kitap.

Demirtaşlı, N. (2016, September). Hesap verebilir eğitim sisteminde bir paydaş olarak öğretmenlerin TEOG (temel eğitimden orta ögretime geçiş) uygulamasına yönelik görüşleri. Paper presented at the 5th International Congress on Measurement and Evaluation in Education and Psychology, Antalya, Turkey.

Dulfer, N., Polesel, J. \& Rice, S. (2012). The Experience of Education: The impacts of high stakes testing on school students and their families. An Educator's Perspective, Sydney, Whitlam Institute

ERG. (2017). PISA 2015: Genel bulgular ve eğilimler. Retrieved from http://www.egitimreformugirisimi.org/wp-content/uploads/2017

Hall, R. V., \& Houten, R. V. (1983). Managing behavior, behavior modification: The measurement of behavior. Austin, Texas: Pro-ed.

Kalkınma Bakanlığı. (2013). Onuncu kalkınma planı 2014-2018. Ankara: TC. Kalkınma Bakanlığı.

Milli Eğitim Bakanlığı. (1973). Milli eğitim temel kanunu. Retrieved from http://www.mevzuat.gov.tr/MevzuatMetin/1.5.1739.pdf.

Milli Eğitim Bakanlığı EARGED. (2010). Seviye belirleme sınavının değerlendirilmesi. Ankara: Millî Eğitim Bakanlı̆̆ı.

Milli Eğitim Bakanlığı. (2010). PISA 2006 projesi ulusal nihai rapor. Ankara: Millı̂ Eğitim Bakanlığı.

Milli Eğitim Bakanlığı. (2011). TIMSS 2007 ulusal matematik ve fen raporu 8. siniflar. Ankara: Millî Eğitim Bakanlığı.

Milli Eğitim Bakanlığı. (2012). İlköğretimden ortaöğretime ortaöğretimden yükseköğretime geçiş analizi. Ankara: Millî Eğitim Bakanlığı.

Milli Eğitim Bakanlığı. (2013). Temel eğitimden ortaöğretime geçiş sistemi. Retrieved from http://www.meb.gov.tr/duyurular/duyurular2013/bigb/tegitimdenoogretimegecis/sunum.pdf.

Milli Eğitim Bakanlığı. (2014). OGES sunum. Retrieved from http://oges.meb.gov.tr/docs2104/sunum.pdf

Milli Eğitim Bakanlığı. (2015). PISA 2012 araştırması ulusal nihai rapor. Ankara: Millı̂ Eğitim Bakanlığı.

Milli Eğitim Bakanlığı Strateji Geliştirme Başkanlığı. (2015). Millı Ĕgitim Bakanlığı 2015-2019 stratejik planı. Retrieved from http://sgb.meb.gov.tr/www/mill-egitim-bakanligi-2015-2019.

Milli Eğitim Bakanlığı. (2016a). 2016-2017 ögretim yll ortak sinavlar e-kllavuzu. Retrieved from https://oges.meb.gov.tr/meb_iys_dosyalar.

Milli Eğitim Bakanlığı. (2016b). PISA 2015 ulusal raporu. Ankara: Millı̂ Eğitim Bakanlığı.

New York State Education Department. (2004). The impact of high-stakes exams on students and teachers. Retrieved from http://www.oms.nysed.gov/faru/TheImpactofHighStakesExams_files/ The_Impact_of_High-Stakes_Exams.pdf.

Özkan, M. \& Özdemir, E. B. (2014). Ortaokul 8. sınıf öğrencilerinin ve öğretmenlerinin ortaöğretime geçişte uygulanan merkezi ortak sinavlara ilişkin görüşleri. Journal of History School (JOHS), DOI: $10.14225 / \mathrm{Joh} 641$

Öztürk, F. Z. \& Aksoy, H. (2014). Temel eğitimden ortaöğretime geçiş modelinin 8. sinif öğrenci görüşlerine göre değerlendirilmesi (Ordu ili örneği). Ondokuz Mayis University Journal of Faculty of Education, DOI: $10.7822 /$ omuefd.33.2.8

Sullivan, G. P. (2006). The impact of high stakes testing on curriculum, teaching, and learning. (Doctoral Dissertation, Faculty of the Virginia Polytechnic Institute and State University). Retrieved from https://vtechworks.lib.vt.edu/handle/10919/ 
Şad, S. N. \& Şahiner, Y. K. (2016). Temel eğitimden ortaöğretime geçiş (TEOG) sistemine ilişkin öğrenci, öğretmen ve veli görüşleri. Elementary Education Online, DOI:10.17051/io.2016.78720.

Tavşancıl, E. \& Aslan, E. (2001). İçerik analizi ve uygulama örnekleri. İstanbul: Epsilon.

Yıldırım, A. \& Şimşek, H. (2005). Sosyal bilimlerde nitel araştırma yöntemleri. Ankara: Seçkin.

Zorlu, Z. \& Zorlu, F (2015). Fen ve teknoloji dersinde öğrenme ortamına yönelik öğrencilerin düzeyleri ve öğretmenlerin görüşleri. Route Educational and Social Science Journal, 2(1), 103-114. 